\title{
Probing the Existence, Credibility and Implementation of Occupational Health and Safety Practices in Paramilitary Organisations in Nigeria
}

\author{
Fab. O. Onah ${ }^{1}$, S. O. Anikwe ${ }^{2}$, F. N. Onah ${ }^{1}$, C. U. Agalamanyi ${ }^{1}$ \& C. O. Ugwuibe ${ }^{1}$ \\ ${ }^{1}$ University of Nigeria, Nsukka, Nigeria \\ ${ }^{2}$ Michael Okpara University of Agriculture, Umudike, Nigeria \\ Correspondence: S. O. Anikwe Ph.D, Lecturer I, Department of Industrial Relations and Personnel Managmenet, \\ Michael Okpara University of Agriculture, Umudike, Nigeria.
}

Received: June 4, 2020

doi:10.5430/jms.v11n3p28
Accepted: August 26, 2020

Online Published: September 2, 2020

URL: https://doi.org/10.5430/jms.v11n3p28

This work was supported by Federal Road Safety Corps, Nigeria.

\begin{abstract}
Occupational Health and Safety Management is an area that is concerned with ensuring the safety, health and welfare of people engaged in work. Workers in paramilitary organisations in Nigeria are much more likely than their counterparts in other agencies to be exposed to poor working environments, health and environmental hazards. To this end, the need to assess the level of implementation and problems of health and safety practices in paramilitary organisations in Nigeria becomes very paramount. The major objective of this study was to the assess occupational health and safety policies and programmes in paramilitary organisations in Nigeria. The study observed that the strategic problems of occupational health and safety in these organisations are ineffective monitoring and enforcement of occupational health and safety policies and inadequate budgetary allocation. The study recommended that adequate budgetary provision should be encouraged and officers should be adequately trained to enable them take proactive measures.
\end{abstract}

Keywords: occupational health and safety, health and safety policies, health and safety practices, paramilitary organisations

\section{Introduction}

Safety and Health Management is an area that is concerned with ensuring the safety, health and welfare of people engaged in work or employment. It goes further to protect co-workers, family members, employers, customers, suppliers, nearby communities and other members of the public who are impacted by the workplace environment (Ferris and Buckley, 2006).

Occupational safety and health (OSH) is generally defined as the science of the anticipation, recognition, evaluation and control of hazards arising in or from the workplace that could impair the health and well-being of workers, taking into account the possible impact on the surrounding communities and the general environment. This domain is necessarily vast, encompassing a large number of disciplines and numerous workplace and environmental hazards. A wide range of structures, skills, knowledge and analytical capacities are needed to coordinate and implement all of the "building blocks" that make up national OSH systems so that protection is extended to both workers and the environment.

Occupational health and safety is a key element in achieving sustained decent working conditions and strong preventive safety cultures in many organisations. Close to 80 per cent of all ILO standards and instruments are either wholly or partly concerned with issues related to occupational health and safety. A large number of areas of ILO activity include an OSH or OSH-related component. This breadth of penetration gives a clear indication of the continued importance of occupational health and safety as a core element of ILO activity and of the Decent Work Agenda in particular.

In Nigeria, especially in the paramilitary organisations, the fatality, accident and disease figures are alarming but investment decisions continue to be made in disregard of safety, health and environmental considerations. In the 
scramble for capital, the pressures of globalization and increasingly stiff competition tend to deflect attention from the long-term economic benefits of a safe and healthy working environment for the employees of these paramilitary organisations.

While the international press reports major on industrial accidents, the many work-related deaths that occur every day go virtually unrecorded, especially in the northern zone of the country. Paramilitary employees in Nigeria continue to face serious risks in their day to day activities. To reduce the human suffering, financial loss and environmental degradation associated with these risks, there is a need for increased and sustained action to promote occupational health and safety in Nigeria paramilitary organisations. This concern forms the substratum for this research.

The human, social and economic costs of occupational accidents, injuries and diseases and major industrial disasters have long been cause for concern at all levels from the individual workplace to the national and international. Measures and strategies designed to prevent, control, reduce or eliminate occupational hazards and risks have been developed and applied continuously over the years to keep pace with technological and economic changes in Nigeria parastatals. Despite the concern and some measures, occupational accidents and diseases are still too frequent and their cost in terms of human suffering and economic burden continues to be very significant.

According to the European Statistics on Accidents at Work (ESAW), every year in the 15 Member States of the European Union (EU) before the enlargements of 2004 and 2007 about 5,000 workers were killed in accidents at work and about 5 million workers were victims of accidents at work leading to more than three days' absence from work (EU, 2004). The story and regrettable statistics are the same in India, China, Latin America, Carbeak and sub-Saharan Africa.

Workers in paramilitary organisations in Nigeria are much more likely than their counterparts in other agencies to be exposed to poor working environments, low safety and health standards, and environmental hazards. Consequently, they suffer poor health or injury as a result of the nature of their job. Most employees in Nigeria paramilitary organisations have little or no knowledge of the risks they face and how to avoid them. The nature of their job makes it almost impossible for governments to collect the vital statistics needed to take appropriate remedial action, and, since much of their work take place on the roads, homes, fields, and offices, inspectorates find it rather difficult to investigate working conditions or get information and advice to the people who need it. Despite this worrying situation, awareness of the magnitude of the problem remains surprisingly modest in Nigeria. The inadequate dissemination of knowledge and information hampers action, especially in developing countries like Nigeria. It also limits the capacity to design and implement effective policies and programmes that addresses employee health and safety at work.

To this end, the need to assess the level of implementation, compliance and problems of health and safety policies and practices in paramilitary organisations in Nigeria becomes very paramount. The research brings to the fore the need to take on the situation proactively in order to make valuable contributions to reforms in that area for the public sector. Studies in this area are currently scanty in Nigeria and reforms appear to be by-passing issues of occupational health and safety, particularly in the paramilitary organisations, hence the need for this study.

The broad objective of this study is to assess the occupational health and safety policies and programmes in paramilitary organisations in South-East Nigeria.

The specific objectives are to; (i) Examine the implementation of occupational health and safety policies and practices in paramilitary organisations in South-East Nigeria; (ii) Ascertain the strategic problems of occupational health and safety practices in paramilitary organisations in South-East Nigeria.

\section{Conceptual Issues}

\subsection{Occupational Health and Safety (OSH) in Nigeria: Current Status}

Occupational Health and Safety in Nigeria can be traced back to the slave trade period. According to Kalejaiye (2013), records show that the medical examination board of the Liverpool infantry introduced occupational health in Nigeria in 1789. Kalejaiye (2013) further reports that the responsibility of this board is to promote the health of the British slave dealers in Africa. He also indicated that after these early stages, the health service was established by Colonel Luggard (who was once the Governor-General of Nigeria) to care for the health and welfare of the colonial administrators and British soldiers; then, after many years, due to the poor working conditions of workers, occupational health services were introduced in some Nigerian industries, and the Occupational Health Legislation Act established. Kalejaiye (2013) asserts that due to the effect of improved mechanisation on the health and welfare 
of workers, the occupational health unit in the Federal Ministry of Health and the Institute of Occupational Health in Oyo State Ministry of Health were established.

Nigeria signed the Geneva Convention in 1981 (Adeogun \& Okafor, 2013), yet 32 years on, implementation of proceedings of the convention is insignificant. Adeogun \& Okafor (2013) report that OSH in Nigeria is still nothing to boast of; in the same way, Diugwu et al. (2012) and Okolie \& Okoye (2012) maintain that OSH in Nigeria is not up to standard.

For instance, although there are no reliable accident data in Nigeria (Idoro 2008; Okolie \& Okoye, 2012), a study by Ezenwa (2001) over a 10-year period (1987-1996) of fatal injuries reported to the Federal Ministry of Labour and Productivity (Inspectorate Division) shows that out of 3183 injuries reported, 71 were fatal. In fact between 1990 and 1994, the overall fatality rate as recorded by the Ezenwa (2001) is $22 \%$ of the above reported cases. This explains why Idoro (2011) in a study of 42 construction contractors in Nigeria, clearly observed that the best available safety record is 5 injuries per worker and 2 accidents per 100 workers in 2006. These records seem to be high whether compared to other countries or not. However, this is not a true representation of what obtains in Nigerian factories (Ezenwa, 2001) because the records are worse than stated above, as the poor state of OSH regulatory system in the country does not encourage compulsory reporting of accidents (Ezenwa 2001; Idoro 2008), which is a major requirement in OSH regulations. Diugwu et al. (2012) strongly believed that the lacuna in OSH in Nigeria lies on the dysfunctional health and safety laws in the country. Owing to this difficulty, all the sectors in the country seems to be clearly unregulated.

\subsection{Occupational Health and Safety Legislation in Nigeria}

The National Policy on Occupational Health and Safety is based on the provisions of Section 17 of the 1999 Constitution of the Federal Republic of Nigeria stating that the State social order is founded on the ideals of Freedom, Equality and Justice (ILO, 2016). International Labour Organisation in their Nigeria Country Profile on Occupational Health and Safety (2016) mentioned that in Section 17, subsection 3, the State shall direct its policy towards ensuring that:

a) All citizens without discrimination on any group whatsoever have the opportunity for securing adequate means of livelihood as well as adequate opportunity to secure suitable employment.

b) Conditions of work are just and humane and that there are adequate facilities for leisure and for social, religious and cultural life.

c) The health, safety and welfare of all persons in employment are safeguarded and not endangered or abused.

d) There are adequate medical and health facilities for all persons.

e) There is equal pay for equal work without discrimination on account of sex, or on any other ground whatsoever.

In addition, the 1999 Constitution (as amended) makes safety, health and welfare of labour an extent of Federal and State Legislative Powers. Item 34 of Part I (Exclusive Legislative List), of the Second Schedule of the Constitution stated labour as including Trade Unions, industrial relations, conditions, safety and welfare of labour and industrial disputes (ILO, 2016).

Furthermore, International Labour Organisation in their Nigeria Country Profile on Occupational Health and Safety (2016) observed that Section 17 of the Part II (Concurrent Legislative List) of the same Second Schedule of the Constitution, on Extent of Federal and State Legislative Powers, stated that the National Assembly may make laws for the federation or any part thereof with respect to the following:

a) The health, safety and welfare of persons employed to work in factories, offices or other premises or inter-state transportation and commerce including the training, supervision and qualification of such persons

b) The regulation of ownership and control of business enterprises throughout the Federation for the purpose of promoting, encouraging or facilitating such ownership and control by citizens of Nigeria.

c) The establishment of research centres for agricultural studies

d) The establishment of institutions and bodies for the promotion or financing of industrial, commercial or agricultural development of the State.

According to ILO (2016), major legislations that have been enacted to provide for the safety and health of Nigeria workforce include:

- The Factories Act, CAP F1, Laws of the Federation of Nigeria (LFN), 2004 
- Employees Compensation Act, 2010

- Nigerian Minerals and Mining Act, 2007

- Nigerian Nuclear Safety and Radiation Act, 1995

Other identified related Laws that seek to give guidance to the implementation of occupational safety and health in the country are:

- Nigeria Basic Ionising Radiation Regulations, 2003

- Nigerian Radiation Safety in Nuclear Regulations, 2006

- Minerals Oils (Safety) Regulations, 1962

- Petroleum (Drilling and Petroleum) Regulations, 1967

- National Environmental Standards and Regulations Enforcement Agency (Establishment) Act, 2007

- Lagos State Safety Commission Law, 2011

- Five Services Regulation, 1998

Nigeria became a member of the ILO upon gaining independence in 1960. Nigeria has ratified forty (40) ILO Conventions till date, out of which ten (10) has been automatically denounced. The country has presently three (3) core occupational safety and health Conventions in place, namely: C155 - Occupational Safety and Health, 1981; C032 - Protection against Accidents (Dockers) 1932; and C019 - Equality of Treatment (Accident Compensation) 1925 (ILO, 2016).

\subsection{Occupational Health and Safety Violations in Nigeria}

There are laws and regulations concerning occupational health and safety in Nigeria but sadly enough the level of compliance to those rules is abysmal in some quarters. While it is all well and good to make laws, those laws are useless if they are not complied with, they cannot be enforced or are enforced only in certain circumstances, for certain people.

Some of the numerous health and safety violations in Nigeria, according to Idubor \& Oisamoje (2013) are in the areas of hours of work, safety appliance, and provision of a safe workplace (Ale, 2012; Ogundimu, 2012).

There have also been reported cases of staff of the Power Holding Company of Nigeria ( $\mathrm{PHCN}$ ) been electrocuted apparently because they were not furnished with the proper safety tools and equipment required to carry out their duties. The situation is so worrisome to the extent that some PHCN field workers have even been lynched because of power outage by irate mobs. In recent history, a female teacher was lynched in Northern Nigeria, her corpse and car burnt because she did not allow cheating in an examination. Cases are replete of Federal Road Safety Corps (FRSC) staff being killed or extremely wounded on the highways while carrying out their legitimate duties. All these unimaginable acts generate grievous negative implications on the performance and morale of employees. This in turn can lead to distressing situations that can negatively affect and destroy their health.

\subsection{Components of an Effective OHS Management System}

Workers' Compensation Board of British Columbia (2019) suggested the following elements of an effective OHS management system. The scope and complexity of the system may vary, depending on the size and hazards of your workplace and the nature of the work performed.

- Management leadership and commitment: Leadership and commitment by senior management provides the vision, establishes policy, sets goals, and provides resources to lead and support the implementation of OHS management programs and system.

- Safe work procedures and written instructions: Safe work procedures and practices ensure that everyone in the organization knows their responsibilities and can perform their duties effectively. There should be safe work procedures on an organizational level, such as how to conduct a risk assessment, as well as on a worker level, such as how to lock out properly.

- Health and safety training and instruction: Everyone in the workplace needs to understand their responsibilities when it comes to implementing and maintaining a healthy and safe workplace. Supervisors must provide adequate instruction and oversight to workers so they can safely perform their work.

- Identifying hazards and managing risk: Managing the risk in the workplace includes identifying hazards, assessing the risks those hazards present, and controlling the risks to prevent your workers from getting injured. 
- Inspection of premises, equipment, workplaces \& work practices: Workplace inspections can help in continually identifying hazards and preventing unsafe working conditions from developing.

- Investigation of incidents: Conducting incident investigations helps identify immediate, and root causes of unsafe conditions. It also identifies ways to prevent similar incidents from happening in the future.

- Program administration: Maintaining accurate records of OHS management system activities will provide useful information to help an organisation to continually improve.

\subsection{Occupational Health and Safety Issues for the Paramilitary}

Paramilitary duties and jobs are among the most dangerous and therefore require special training. The hazards that are very common with paramilitary duties, according to Canadian Centre for Occupational Health \& Safety (2019) include:

Violent attacks; Standing or sitting for long hours; Exposure to contagious and infectious diseases from people, animals, needles, and other sources; Exposure to various chemical or biological hazards; Pain from physical overexertion and prolonged or awkward body postures; Exposure to extreme temperatures and radiation.

Extreme Noise; Slips, trips and falls; Fatigue from shift work; Psychological stress or trauma; Working alone; Risk of injury from the various locations where they may be called to: fire, explosion, unstable structures and surfaces, falling objects, or working at heights or near traffic, water, confined spaces, large crowds, violent situations and danger of driving at high speeds, often in difficult traffic or weather conditions.

\section{Methodology}

The study made use of both qualitative and quantitative data collection. It involved critical analysis of health and safety policies and practices being adopted in the paramilitary organisations in Nigeria. Four organisations in the South East namely, The Federal Road Safety Corps (FRSC), Federal Fire Service Nigeria, Nigeria Correctional Service and Nigeria Security and Civil Defence Corps (NSCDC) were studied. Paramilitary organisations in Nigeria are guided by the same policles nationwide with headquarters at the centre. Therefore, information from the South East represents and mirrors information from other parts of Nigeria considerably.

\subsection{Participants/Procedure}

The Population of the study is approximately 15,000 which comprises of all the employees in the four paramilitary organisations in the South Eastern States of Nigeria. Using Yamene formular for sample size, the sample of the study consisted of a respondent. This was drawn from the four paramilitary organisations in the South East.

In-depth interviews, Focus Group Discussions (FGD), and questionnaire were used to generate the needed data. Sixty (60) employees, 15 each from the four organisations, participated in the FGD. Interviews were conducted with heads of operations, Directors, unit heads and employees occupying key positions in different categories of the selected paramilitary organisations.

Questionnaires were developed to assess the occupational health and safety levels they have been exposed to, areas unattended to and problems of implementation. The survey involved 60 respondents. Respondents are those considered knowledgeable enough to offer useful information. A stratified random sampling was used in the selection of the sample. The reason for the adoption of this sampling technique is to avoid possible bias and ensure that employees in different categories/cadres are selected.

Apart from the above arrangement for information gathering, two workshops for critical stakeholders and professionals in the sector were organised to stimulate interaction and broaden information base on the subject matter which is occupational health and safety.

\subsection{Design/Statistical Analysis}

This is a cross-sectional study. Data from samples are collected and analysed, thereby making an accurate assessment of the characteristics of the population. Premised on this, a cross-sectional study based on the analysis of health and safety policies and practices as it affects paramilitary organisations in Nigeria were embarked upon.

For the qualitative data, descriptions of major findings were made and conclusions drawn from the descriptions. For the quantitative data, descriptive statistics were used to present the basic information on the research participants while correlation and regression analyses were used to test the research hypotheses.

The QSR Nvivo software were used for the qualitative data analysis while Statistical Package for the Social Sciences (SPSS) were used for analysing the quantitative data. 


\section{Data Presentation, Analysis and Findings}

\section{Introduction}

This section focused on the presentation and analysis of the data collected. The objective of this section was examined and analyzes the information gathered from both the primary and secondary sources of data collection. Five point likert scales were used to design the questionnaire so as to pave way for easy understanding of the questions and to allow the respondents to give simple and accurate answers to the questions.

Data presentation and analysis was discussed under the following sub-themes:

(i) The implementation of occupational health and safety policies and practices in paramilitary organisations in South-East Nigeria.

(ii) The strategic problems of occupational health and safety practices in paramilitary organisations in South-East Nigeria.

\section{(i) The implementation of occupational health and safety policies and practices in paramilitary organisations in} South-East Nigeria.

The table below shows the frequency calculations of responses from our respondents on the implementation of occupational health and safety policies and practices in paramilitary organisations under the area of our study. Questions 1 and 5 in the questionnaire were used to determine this objective.

\section{A. Analysis of Question One}

Table 1. Existence of health and safety practices in your organization

\section{Cross tab}

\begin{tabular}{|c|c|c|c|c|c|c|c|}
\hline & & & Organization & & & & \\
\hline & & & $\begin{array}{l}\text { Nigerian } \\
\text { Correctional } \\
\text { Service }\end{array}$ & $\begin{array}{l}\text { Nigeria Security } \\
\text { and Civil Defence } \\
\text { Crops }\end{array}$ & $\begin{array}{l}\text { Federal/State } \\
\text { Fire Service }\end{array}$ & $\begin{array}{l}\text { Federal Road } \\
\text { Safety Corps }\end{array}$ & Total \\
\hline \multirow{13}{*}{$\begin{array}{l}\text { Health and Safety } \\
\text { Practices exist in } \\
\text { your organization }\end{array}$} & Strongly & Count $\%$ & 10 & 4 & 6 & 8 & 28 \\
\hline & & within Health and & & & & & \\
\hline & & $\begin{array}{l}\text { Safety Practices exist } \\
\text { in your }\end{array}$ & $35.7 \%$ & $14.3 \%$ & $21.4 \%$ & $28.6 \%$ & $100.0 \%$ \\
\hline & & $\begin{array}{l}\text { Organization } \% \text { within } \\
\text { organization }\end{array}$ & 55.6 & $40.0 \%$ & $37.5 \%$ & $50.0 \%$ & $46.7 \%$ \\
\hline & Agree & Count $\%$ & 6 & 4 & 8 & 8 & 26 \\
\hline & & $\begin{array}{l}\text { Within Health and } \\
\text { Safety Practices exist } \\
\text { in your }\end{array}$ & $23.1 \%$ & $15.4 \%$ & $30.8 \%$ & $30.8 \%$ & $100.1 \%$ \\
\hline & & $\begin{array}{l}\text { Organization } \% \text { within } \\
\text { organization }\end{array}$ & $33.3 \%$ & $40.0 \%$ & $50.0 \%$ & $30.0 \%$ & $43.3 \%$ \\
\hline & Undecided & Count $\%$ & 0 & 2 & 1 & 0 & 3 \\
\hline & & $\begin{array}{l}\text { Within Health and } \\
\text { Safety practices exist } \\
\text { in your }\end{array}$ & $0 \%$ & $66.7 \%$ & $33.3 \%$ & $0 \%$ & $100.0 \%$ \\
\hline & & $\begin{array}{l}\text { Organization\% within } \\
\text { organization }\end{array}$ & $0, \%$ & $20.0 \%$ & $6.2 \%$ & $0 \%$ & $5.0 \%$ \\
\hline & Disagree & Count $\%$ & 2 & 0 & 0 & 0 & $2 \%$ \\
\hline & & $\begin{array}{l}\text { Within Health and } \\
\text { Safety practices exist } \\
\text { in your }\end{array}$ & $100.0 \%$ & $0 \%$ & $0 \%$ & $0 \%$ & $100.0 \%$ \\
\hline & & $\begin{array}{l}\text { Organization } \% \text { within } \\
\text { organization }\end{array}$ & $11.1 \%$ & $0 \%$ & $0 \%$ & $0 \%$ & $3.3 \%$ \\
\hline
\end{tabular}




\begin{tabular}{|c|c|c|c|c|c|c|}
\hline \multirow{4}{*}{$\begin{array}{l}\text { Strong } \\
\text { Disagree }\end{array}$} & Count $\%$ & 0 & 0 & 1 & 0 & 1 \\
\hline & Within Health and & & & & & \\
\hline & $\begin{array}{l}\text { Safety practices exist } \\
\text { in your }\end{array}$ & $0 \%$ & $0 \%$ & $100.0 \%$ & $0 \%$ & $100.0 \%$ \\
\hline & $\begin{array}{l}\text { Organization } \% \text { within } \\
\text { organization }\end{array}$ & $0 \%$ & $0 \%$ & $6.2 \%$ & $0 \%$ & $1.7 \%$ \\
\hline \multirow[t]{4}{*}{ Total } & Count $\%$ & 18 & 10 & 16 & 16 & $60 \%$ \\
\hline & Within Health and & & & & & \\
\hline & $\begin{array}{l}\text { Safety practices exist } \\
\text { in your }\end{array}$ & $30.0 \%$ & $16.7 \%$ & $26.7 \%$ & $26.7 \%$ & $100 \%$ \\
\hline & $\begin{array}{l}\text { Organization } \% \text { within } \\
\text { organization }\end{array}$ & $100.0 \%$ & $100.0 \%$ & $100.0 \%$ & $100.0 \%$ & $100.0 \%$ \\
\hline
\end{tabular}

Source: Research Survey, 2019.

\section{Analysis and Observations by Paramilitary Organizations}

From Table 1 above, it was observed that officers of Nigeria Correctional Service in the south-east strongly agreed that health and safety practices exist in their organization with $55.6 \%, 33.3$ of them agreed, $0 \%$ were undecided, $11.1 \%$ of the officers disagreed while $0 \%$ strongly disagreed.

Officers of Nigeria Security and Civil Defence Corps strongly agreed with 40\%, agreed with $40 \%$, undecided with $20 \%$, disagreed and strongly disagreed with $0 \%$ respectively that health and safety practices exist in their organization.

Federal/State Fire Service officers believe that health and safety practices exist in their organization with $37.5 \%$ and $50 \%$ of them strongly agreeing and agreeing (respectively). $6.2 \%$ of the officers were undecided, $0 \%$ disagreed while $6.2 \%$ strongly disagreed.

Officers of Federal Road Safety Commission also corroborated the opinions of the other paramilitary organisations with $50 \%$ of their officers agreeing and strongly agreeing respectively, that health and safety practices exist in their organization. $0 \%$ of the officers were undecided, $0 \%$ disagreed and $0 \%$ strongly disagreed on the above statement.

Table 2. Cross-tabbing of Question; compliance with the health and policy standards created by appropriate regulatory bodies in Nigeria

\section{Cross tab}

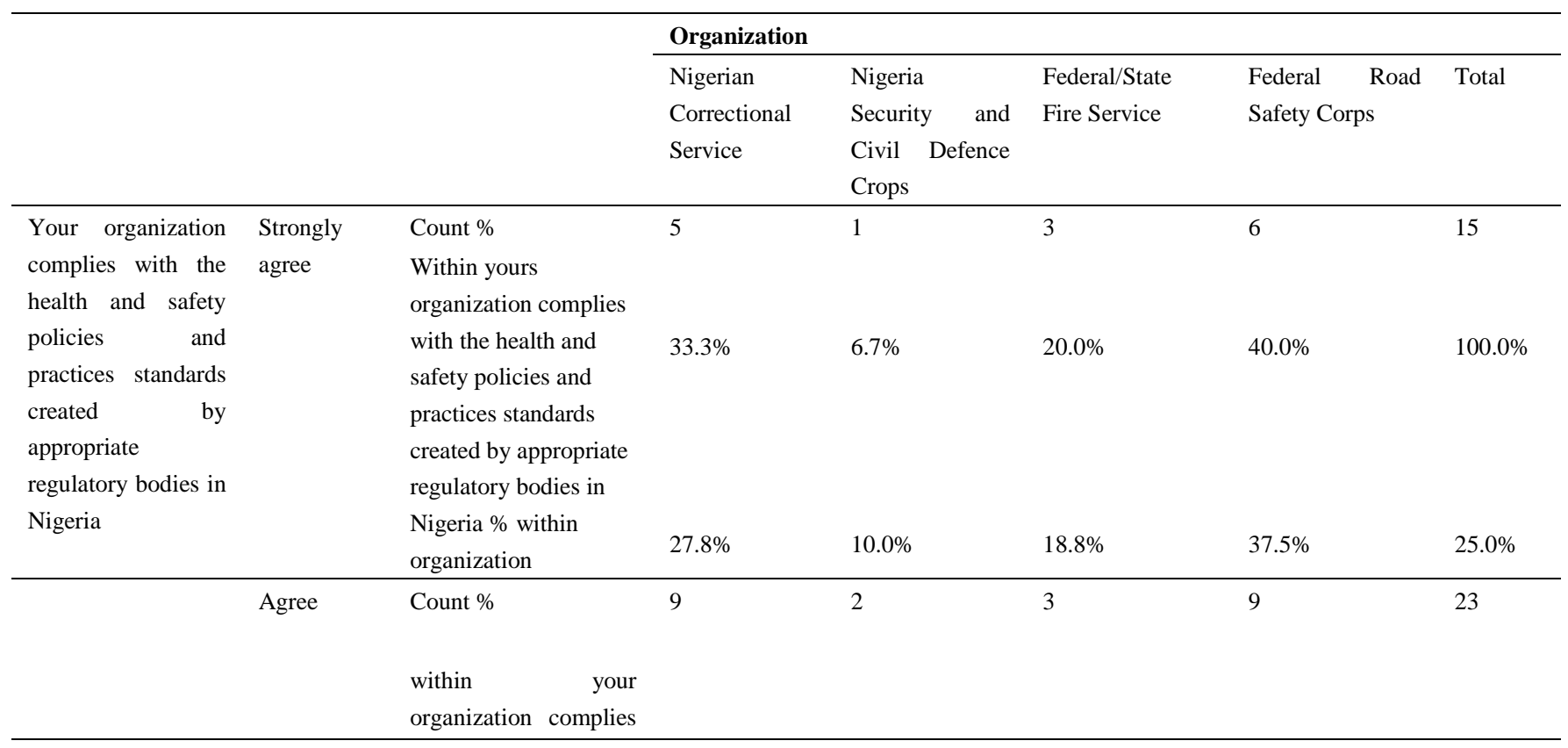




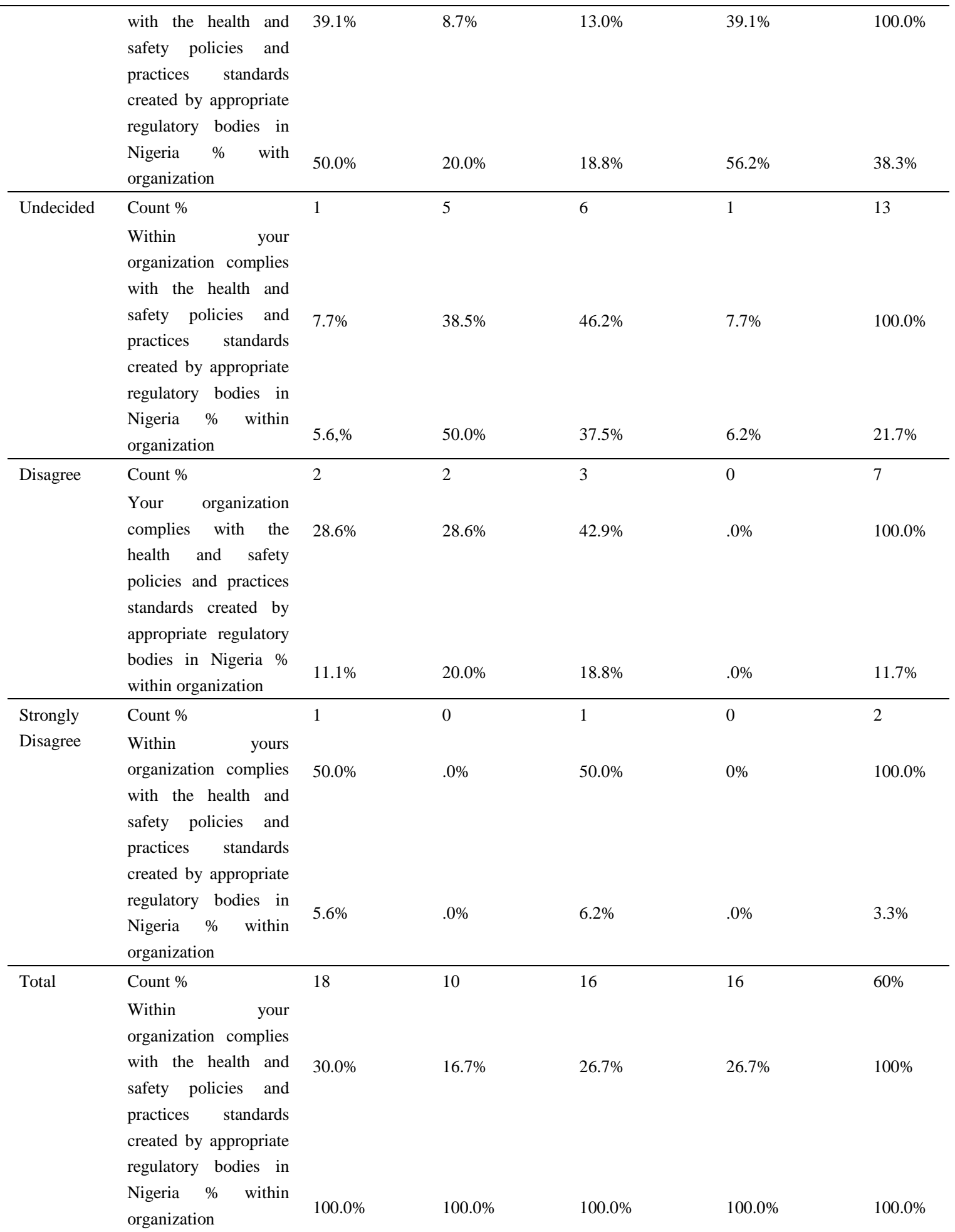

Source: Field Survey, 2019.

\section{Analysis and Observations by Paramilitary Organizations}

From Table 2, officers of Nigeria Correctional Service believe that their organization complies with the health and policy standards created by appropriate regulatory bodies in Nigeria. $27.8 \%$ of them strongly agreed, $50 \%$ agreed, $5.6 \%$ were undecided, $11.1 \%$ disagreed while $5.6 \%$ strongly disagreed on the subject. 
Nigeria Security and Defence Corps were undecided on whether their organisation complies with the health and policy standards created by appropriate regulatory bodies in Nigeria with $50 \%$ response. $10 \%$ of the officers strongly agreed, $20 \%$ agreed, $20 \%$ disagreed while $0 \%$ strongly disagreed. This shows that the officers were undecided in their opinion.

Officers of Federal/State Fire Service were also undecided on whether their organisation complies with the health and policy standards created by appropriate regulatory bodies in Nigeria. They were undecided with $37.5 \%$, strongly agreed with $18.8 \%$, agreed with $18.8 \%$, disagreed with $18.8 \%$ while $6.2 \%$ strongly disagreed. It can be observed that the officers towed same path with Nigeria Civil Defence Corps officers.

Federal Road Safety Commission officers had a different opinion from the former discussed officers as they strongly agreed that their organisation complies with the health and policy standards created by appropriate regulatory bodies in Nigeria with $37.5 \% .56 \%$ of them agreed, $6.2 \%$ were undecided, $0 \%$ disagreed while $0 \%$ strongly disagreed.

\section{Findings}

It can be deduced from the analysis of table 4.1 that the officers of the paramilitary organisations under the area of our study (Enugu, Abia and Imo State) upheld the statement that health and safety practices exist in their organization. This buttresses the first objective and signified that occupational health and safety policies and practices are being implemented in their organisation.

However, table 4,2 apparently shows that the officers of paramilitary organisations in the south east were undecided on whether their organisation complies with the health and policy standards created by appropriate regulatory bodies in Nigeria. Some of them believe that their organisation complies with the health and policy standards created by appropriate regulatory bodies in Nigeria while some of the officers did not agree with the statement. These two tables however signify that paramilitary organisations in the south east implements occupational health and safety policies and practices in their organisations.

(ii) The Strategic Problems of Occupational Health and Safety Practices in Paramilitary Organisations in South-East Nigeria.

The table below shows the frequency calculations of responses from our respondents on the Strategic Problems of Occupational Health and Safety Practices in Paramilitary Organisations in South-East Nigeria. Questions 25 and 32 in the questionnaire were used to determine this objective.

\section{A. Analysis of Question 25}

Table 3. Scale of occupational health and safety practices in your organisation

\section{Cross tab}

\begin{tabular}{|c|c|c|c|c|c|c|c|}
\hline & & & \multicolumn{5}{|l|}{ Organization } \\
\hline & & & $\begin{array}{l}\text { Nigerian } \\
\text { Correctional } \\
\text { Service }\end{array}$ & $\begin{array}{l}\text { Nigeria } \\
\text { Security and } \\
\text { Civil Defence } \\
\text { Crops }\end{array}$ & $\begin{array}{l}\text { Federal/State } \\
\text { Fire Service }\end{array}$ & $\begin{array}{l}\text { Federal Road } \\
\text { Safety Corps }\end{array}$ & Total \\
\hline \multirow{9}{*}{$\begin{array}{l}\text { Occupational health } \\
\text { and safety practices } \\
\text { in your } \\
\text { organizations seems } \\
\text { not to be in full } \\
\text { scale }\end{array}$} & Strongly & Count $\%$ & 10 & 3 & 7 & 3 & 23 \\
\hline & agree & Within occupational & & & & & \\
\hline & & $\begin{array}{l}\text { health and safety } \\
\text { practices in your }\end{array}$ & $45.5 \%$ & $13.0 \%$ & $30.4 \%$ & $13.0 \%$ & $100.0 \%$ \\
\hline & & $\begin{array}{l}\text { organization seems } \\
\text { not to be in full }\end{array}$ & & & & & \\
\hline & & $\begin{array}{l}\text { scale } \% \text { within } \\
\text { organization }\end{array}$ & $55.6 \%$ & $30.0 \%$ & $43.8 \%$ & $18.8 \%$ & $38.3 \%$ \\
\hline & Agree & Count $\%$ & 8 & 6 & 7 & 5 & 26 \\
\hline & & $\begin{array}{l}\text { Within occupational } \\
\text { health and safety }\end{array}$ & & & & & \\
\hline & & $\begin{array}{l}\text { practices in your } \\
\text { organization seems } \\
\text { not to be in full }\end{array}$ & $30.8 \%$ & $23.1 \%$ & $26.9 \%$ & $19.2 \%$ & $100.0 \%$ \\
\hline & & scale $\%$ within & $44.4 \%$ & $60.0 \%$ & $43.8 \%$ & $31.2 \%$ & $43.3 \%$ \\
\hline
\end{tabular}




\begin{tabular}{|c|c|c|c|c|c|c|}
\hline & organization & & & & & \\
\hline \multirow[t]{7}{*}{ Undecided } & Count $\%$ & 0 & 1 & 1 & 4 & 6 \\
\hline & Within occupational & $0 \%$ & $167 \%$ & $167 \%$ & $667 \%$ & $1000 \%$ \\
\hline & practices in your & & & & & \\
\hline & organization seems & & & & & \\
\hline & not to be in full & & & & & \\
\hline & scale $\%$ within & $.0 \%$ & $10.0 \%$ & $6.2 \%$ & $25.0 \%$ & $10.0 \%$ \\
\hline & organization & & & & & \\
\hline \multirow[t]{8}{*}{ Disagree } & Count $\%$ & 0 & 0 & 0 & 2 & 2 \\
\hline & Within occupational & & & & & \\
\hline & health and safety & & & & & \\
\hline & practices in your & $.0 \%$ & $0 \%$ & $.0 \%$ & $100.0 \%$ & $100.0 \%$ \\
\hline & organization seems & & & & & \\
\hline & not to be in full & & & & & \\
\hline & scale \% within & $.0 \%$ & $.0 \%$ & $.0 \%$ & $12.5 \%$ & $3.3 \%$ \\
\hline & organization & & & & & \\
\hline \multirow{8}{*}{$\begin{array}{l}\text { Strongly } \\
\text { Disagree }\end{array}$} & Count $\%$ & 0 & 0 & 1 & 2 & 3 \\
\hline & Within occupational & & & & & \\
\hline & health and safety & $.0 \%$ & $.0 \%$ & $33.3 \%$ & $66.7 \%$ & $100.0 \%$ \\
\hline & practices in your & & & & & \\
\hline & organization seems & & & & & \\
\hline & not to be in full & & & & & \\
\hline & scale $\%$ within & $.0 \%$ & $.0 \%$ & $6.2 \%$ & $12.5 \%$ & $5.0 \%$ \\
\hline & organization & & & & & \\
\hline \multirow[t]{8}{*}{ Total } & Count $\%$ & 18 & 10 & 16 & 16 & 60 \\
\hline & Within occupational & & & & & \\
\hline & health and safety & $30.0 \%$ & $16.7 \%$ & $26.7 \%$ & $26.7 \%$ & $100.0 \%$ \\
\hline & practices in your & & & & & \\
\hline & organization seems & & & & & \\
\hline & not to be in full & $100.0 \%$ & $100.0 \%$ & $100.0 \%$ & $100.0 \%$ & $100.0 \%$ \\
\hline & scale $\%$ within & & & & & \\
\hline & organization & & & & & \\
\hline
\end{tabular}

Source: Research Survey (2019)

\section{Analysis and Observations by Paramilitary Organizations}

From Table 3, officers of Nigeria Correctional Service strongly believe that their occupational health and safety practices in seems not to be at full scale. $55.6 \%$ of them strongly agreed, $44.4 \%$ agreed, none of them were undecided, disagreed or strongly disagreed on the subject.

Nigeria Security and Defence Corps followed the same path the former officers, as $30 \%$ and $60 \%$ of them strongly agreed and agreed respectively. $10 \%$ were undecided while none of them disagreed nor strongly disagreed.

Officers of Federal/State Fire Service also strongly agreed and agreed with $43.8 \%$ respectively. $6.2 \%$ of them were undecided; none of them disagreed while $6.2 \%$ strongly disagreed.

Federal Road Safety Commission officers did not give a different opinion from the former discussed officers as they strongly agreed that their occupational health and safety practices seems not to be at full scale with $18.8 \% .31 .2 \%$ of them agreed, $25.0 \%$ were undecided, $12.5 \%$ disagreed and strongly disagreed respectively. 


\section{B. Analysis of Question 32}

Table 4. Implications of inadequate budgetary allocation to health and safety programmes in your organisation Cross tab

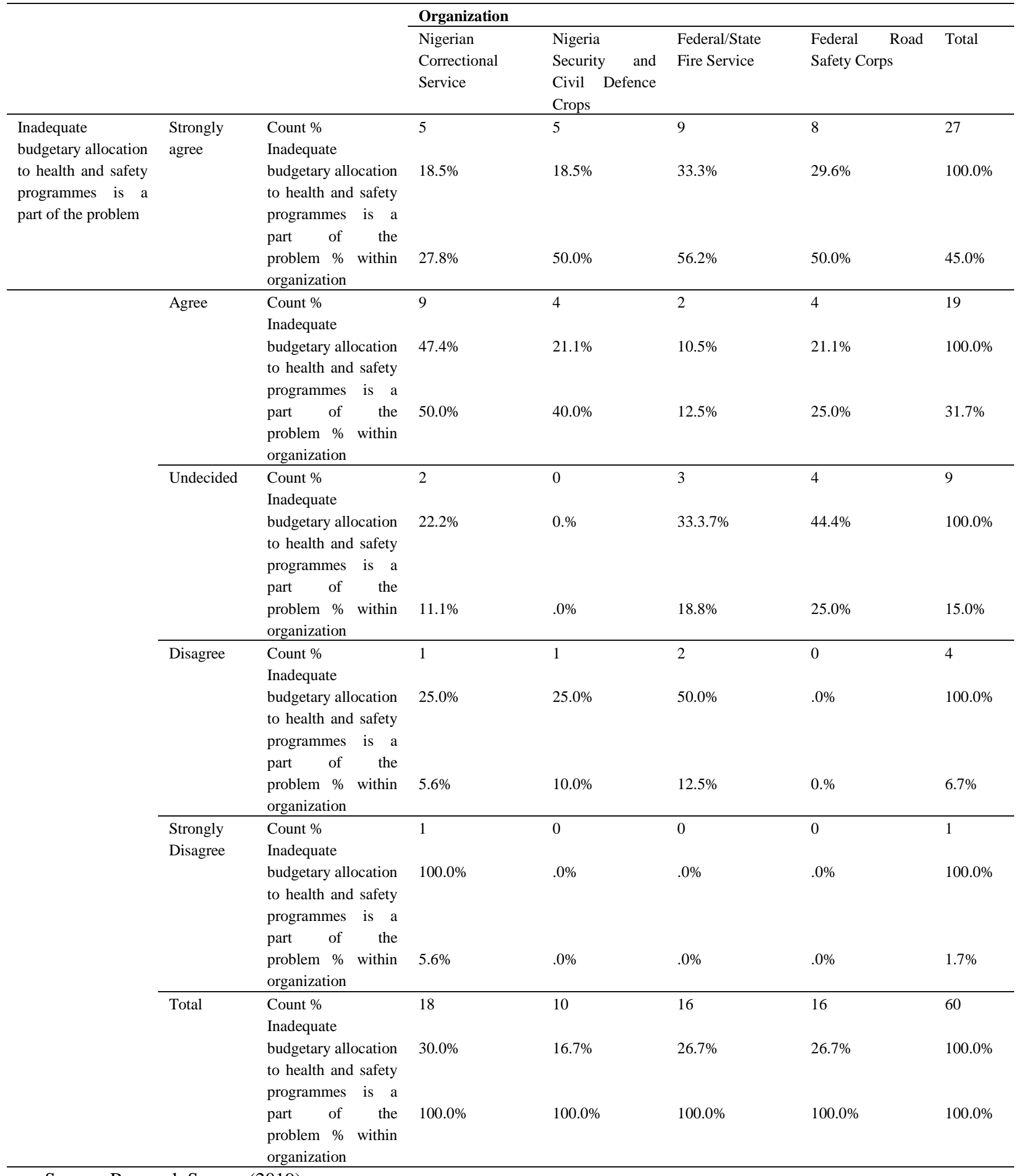

Source: Research Survey (2019) 


\section{Analysis and Observations by Paramilitary Organizations}

From Table 4, officers of Nigeria Correctional Service strongly believe that inadequate budgetary allocation to health and safety programmes is part of the problem. $27.8 \%$ of them strongly agreed, $50.0 \%$ agreed, $11.1 \%$ were undecided, $5.6 \%$ disagreed and strongly disagreed respectively.

Nigeria Security and Defence Corps were more concrete in their level of agreement as $50 \%$ and $40 \%$ of them strongly agreed and agreed respectively. $0 \%$ were undecided, $10 \%$ disagreed while none strongly disagreed.

Officers of Federal/State Fire Service also strongly agreed and agreed with 56.2.0\% and 1.25\% respectively. $18.8 \%$ of them were undecided, $12.5 \%$ of them disagreed while none strongly disagreed.

Federal Road Safety Commission officers did not give a different opinion from the former discussed officers as they strongly agreed that inadequate budgetary allocation to health and safety programmes is part of the problem with $50.0 \% .25 .0 \%$ of them agreed, same $25.0 \%$ were undecided, while $0 \%$ disagreed and strongly disagreed respectively.

\section{Findings}

Data from Tables 3 and 4 were presented and analysed in order to determine the strategic problems of occupational health and safety practices in paramilitary organisations in South-East Nigeria. At the conclusion of the data presentation and analysis of questions 25 and 32, we observed that there exist some strategic problems of occupational health and safety practices in paramilitary organisations in South-East Nigeria, because occupational health and safety practices in these studied organisations seem not to be at full scale. All the officers in the paramilitary organisations in south east Nigeria strongly believe that these problems hinder the success and implementation of health and safety of officers.

Secondly, we observed from the responses generated from table 6.9 that inadequate budgetary allocation to health and safety programmes is part of the problem that hinders the success of occupational health and safety in the studied paramilitary organisations, as the officers all agreed in their responses. From the above discussion, this clearly shows that there exist some strategic problems of occupational health and safety practices in paramilitary organisations in South-East Nigeria.

\section{Discussion}

\section{a. Existence of Health and Safety Practices in the Paramilitary Organizations}

Data generated from the interview conducted signifies that some of the occupational health and safety policies and procedures being observed in these paramilitary organisations are in accordance with provisions of Factories Act and Labour Law (2004). These policies and procedures were discussed below.

- The Act stated that an employer is required to protect the health and safety of workers at the workplace in accordance with the provisions of Factories Act and Labour Law. It is obligatory for the employer, under employment contract to provide safe system and place of work and to take measures to ensure the safety of the worker. It is the duty of the employer to ensure cleanliness in the factory, factories must not be overcrowded during the work. There must be proper ventilation, lighting. drainage of floors and sanitary conveniences.

- Employer must ensure safety of worker from injury to their health and dangers of work and machinery by providing safe workplace and work equipment; by complying with the conditions of health, safety and occupational health; and ensuring that machines and work equipment are installed and kept in safe conditions.

- Workers must not get involved in tasks that can cause injury or that are hazardous such as dangerous liquids and fumes, explosives, and inflammable dusts, gases, vapours and other substances. Workers must receive proper training and work under the supervisor who has thorough knowledge and experience of the machine.

- Employer must also provide and maintain an adequate supply of drinking water, washing facilities, first aid and a place for the workers to store their clothing. It is the duty of the employer to keep health and safety records and makes them available to the inspector, when required.

- Employees must also not wilfully and without reasonable cause do anything likely to endanger themselves or any other person. They should use any means or appliance for securing health or safety provided for their use; and should not wilfully interfere with or misuse any means, appliance, convenience or other item provided to secure health, safety or welfare in the factory. (Section 7-50 of the Factories Act, Cap F1 LFN 2004) 
- The Act also maintained that it is obligatory for the employer to provide free personal protective equipment to the workers. According to the Factories Act, if workers are employed in any process involving excessive exposure to wet or to injurious or offensive substance, suitable protective clothing and appliances, including, where necessary, suitable gloves, footwear, goggles and head coverings, are provided and maintained for the use of such workers. Effective screens are provided to avoid exposure to the electric arc flash if a worker is involved in electric arc welding (Section 47 \& 48 of the Factories Act, Cap F1 LFN 2004)

- In the area of training, the Act maintained that the employer must acquaint the employees before commencement of work about the hazards they might be exposed to in their occupation and train them about the preventive measures that must be taken to ensure health and safety at workplace. A worker is required to abide by the instructions to maintain health and safety at the workplace.

- The Act provided that an inexperienced worker should not be employed at any machine or in any process, being a machine or process that can lead to cause bodily injury, unless he has been fully instructed as to the dangers related to it and the precautions that should be taken into account. Workers must receive sufficient training to work at the machine or in the process; or they work under adequate supervision by a person who has a thorough knowledge and experience of the machine or process (Section 23 of the Factories Act (Cap F1 LFN 2004).

In summary and from the above analysis and discussions, it was observed that the procedures and policies of occupational health and safety in Nigeria are to a large extent being implemented in the paramilitary organisations under the area of our study. The results generated from the questionnaires were complimented by the data generated from our secondary sources and the interview conducted.

Furthermore, we confirmed the responses generated from the questionnaires with the data from our interview source, official government documents and other secondary data sources and we observed the following;

a. Occupational health and safety practices in the studied paramilitary organisations seem not to be at full scale.

Occupational health and safety practices in the paramilitary organisations in South-East Nigeria are not to be at full scale. The reason is not far from the fact that there are no published guidelines regulating the implementation of occupational health and safety Regulations in the country (ILO, 2016). Nigeria Country Profile on Occupational Safety and Health (OSH) (2016) reported that there is no formal National OSH Management System that has been developed by OSH authorities for use in workplace, based on ILO-OSH 2001 and other OSH Management Systems at both National and Enterprise levels. However, there is a National OSH Policy, put in place in 2006to provide some level of guidance. This makes the implementation of occupational health and safety in these paramilitary organisations not to be successful as there is no guideline to follow and there are no regulations to abide by.

It was observed that most organisations and OSH practitioners in Nigeria have been relying on the Factories Act in the implementation of OSH workplace arrangements in their respective organisations and practices. Some large corporations particularly multi-nationals on the other hand have developed their in-house, industry-specific managements systems. The adoption of OSH Management Systems is widely observed in the Oil and Gas, Maritime, Fast Moving Consumable Groups (FMCGs), Aviation and Construction sectors of the economy, but not in paramilitary organisations.

The primary objective of such organisations is the preservation of the safety and wellbeing of their employees, compliance with statutory laws and Regulations of the country and that of their parent country being mostly international organisations bound by their global organisational OSH policies and productivity implications of safety and health in the workplace. Nigeria does not have a National OSH committee in place; this structure exists mostly at the enterprise level.

This programme is geared towards the provision of anti-snake venom to rural agricultural workers as a result of the occupational hazard brought about as a result of their farming activities, particularly in the Northern part of Nigeria.

\section{b. Inadequate budgetary allocation to health and safety programmes}

It was observed that the budgetary allocation to health and safety programmes in Nigeria organisations is very poor. The budgetary allocation for the occupational health and safety (OHS) in Nigeria is summarized in the table below: 
Table 5. OHS budgetary allocation

\begin{tabular}{lll}
\hline Year & OHS (NGN) & EchiTab (NGN) \\
\hline $\mathbf{2 0 1 6}$ & $41,660,716$ & $143,571,974$ \\
$\mathbf{2 0 1 5}$ & Nil & $70,466,179$ \\
$\mathbf{2 0 1 4}$ & $6,208,610$ & $98,946,459$ \\
$\mathbf{2 0 1 3}$ & $5,000,000$ & $140,091,903$ \\
$\mathbf{2 0 1 2}$ & $11,279,768$ & $160,609,492$ \\
$\mathbf{2 0 1 1}$ & $9,016,919$ & $106,355,304$ \\
\hline
\end{tabular}

Source: Nigeria Country Profile on Occupational Safety and Health (2016)

EchiTab Programme: This programme is geared towards the provision of anti-snake venom to rural agricultural workers as a result of the occupational hazard brought about as a result of their farming activities, particularly in the Northern part of Nigeria.

From the budgetary allocation table, it can be observed that in 2015, there was no allocation for occupational health and safety. From 2011 to 2014, the figures were fluctuating from a high amount to a lesser one, then to a higher one. This low budgetary allocation to health and safety does not allow the paramilitary organisations make adequate provisions for its officers that encounter injuries and ill health while on duty.

\section{Outcome}

At the conclusion of this research, the following outcomes were generated;

- The paramilitary organisations in the south east implements occupational safety and health policies in their organisations. This was consistent with our observation, where we observed that the paramilitary organisation complies with the health and policy standards created by appropriate regulatory bodies in Nigeria. Data generated from our findings signifies that some of the occupational health and safety policies and procedures being observed in these paramilitary organisations are in accordance with provisions of Factories Act and Labour Law (2004). It was observed that the procedures and policies of occupational health and safety in Nigeria are to a large extent being implemented in the paramilitary organisations under the area of our study.

- There exist strategic problems of occupational safety and health in paramilitary organisations in South-East Nigeria. This is because occupational health and safety practices in these studied organisations seem not to be at full scale and it was discovered that these problems hinder the success and implementation of health and safety of officers. We also observed that inadequate budgetary allocation to health and safety programmes is part of the problem that hinders the success of occupational health and safety in the studied paramilitary organisations. Other strategic problems include ineffective monitoring of compliance and enforcement of occupational health and safety policies and programmes, deficiency in the collection, dissemination and publication of occupational safety and health information, etc

\section{Recommendations}

Based on the findings of this study, we wish to proffer the following recommendations:

Though the paramilitary organisations in the south east implement occupational health and safety policies and practices in their organisations, these policies should be enhanced by the government making more efforts to strengthen occupational health and safety practices in Nigeria organisations through proper legislation. Legislations in this area are currently not very strong enough and reforms appear to be by-passing issues of occupational health and safety, particularly in the paramilitary organisations.

Occupational health and safety practitioners in Nigeria have been relying on the Factories Act in the implementation of occupational health and safety workplace arrangements in their respective organisations and practices. Government should make adequate arrangements to make laws and establish rules that will guide the practice of occupational health and safety in Nigeria.

Finally, the problems of occupational health and safety practices in paramilitary organisations in South-East Nigeria which include ineffective monitoring of compliance and enforcement of occupational health and safety policies and programmes, deficiency in the collection, dissemination and publication of occupational safety and health 
information, inadequate budgetary allocation to health and safety programmes should be adequately tackled to enhance occupational health and practice in these organisations.

Adequate budgetary provision should be encouraged to help the regulatory bodies function effectively. Officers in charge of occupational health and safety in the organisations should be adequately trained to enable them to appreciate the working environments of the workers and take proactive measures.

\section{References}

Adeogun, B. K., \& Okafor, C. C. (2013). Occupational health, safety and environment (hse) trend in Nigeria. International Journal of Environmental Science, Management and Engineering Research, 2(1), 24-29.

Canadian Centre for Occupational Health \& Safety. (2019). Occupations and workplaces. Retrieved from https://www.ccohs.ca/oshanswers/occup_workplace/police.html

Correll, R. (2019). What is occupational health and safety? Retrieved from https://www.verywellhealth.com/what-is-occupational-health-and-safety-4159865

Diugwu, I. A., Baba, D. L., \& Egila, A. E. (2012). Effective regulation and level of awareness: An expose of the Nigeria's construction industry. Open Journal of Safety Science and Technology, 2, 140-146.

Ezenwa, A. O. (2001). A study of fatal injuries in Nigerian factories. Society of Occupational Medicine, 51(8), 485-489.

Ferris, G. R., \& Buckley, M. R. (2006). Human resources management: perspectives, context, functions and outcomes. New Jersey: Prentice Hall, Englewood Cliff.

Hughes, P., \& Ferret, E. (2010). Introduction to international health and safety at work: The handbook for the NEBOSH international general certificate. Oxford: Butterworth-Heinemann, Elsevier.

Idoro, G. I. (2008). Health and safety management efforts as correlates of performance in the Nigerian construction industry. Journal of Civil Engineering and Management, 14(4), 277-285.

Idoro, G. I. (2011). Comparing occupational health and safety (ohs) management efforts and performance of Nigerian construction contractors. Journal for Construction in Developing Countries, 16(2), 151-173.

Idubor, E. E., \& Oisamoje, M. D. (2013). An exploration of health and safety management issues in nigeria's effort to industrialize. European Scientific Journal, 9(12), 1857-7881.

International Labour Organization. (2003). ILO declaration on fundamental rights at work. Retrieved from www.ilo.org//declaration/lang--en/index.html

International Labour Organisation. (2016). Nigeria country profile on occupational health and safety. Retrieved from https://www.ilo.org/wcmsp5/groups/public/---.../-ro.../wcms_552748.pdf

Kalejaiye, P. O. (2013). Occupational health and safety: issues, challenges and compensation in Nigeria. Peak Journal of Public health and Management, 1(2), 16-23.

Okolie, K. C., \& Okoye, P. U. (2012). Assessment of national cultural dimensions and construction health and safety climate in Nigeria. Science Journal of Environmental Engineering Research, 12, 6-12.

Onyeozili, E. C. (2005). Obstacles to effective policing in Nigeria. African Journal of Criminology and Justice Studies, 1(1), 32-54.

Pedro, E. (2012). Occupational health and safety bill passed. Daily Times, September, 28, 2012. Retrieved from www.dailytimes.com.ng/articles/occupational-safety-and-health-bill-passed

Pomeroy, D. A. (1997). Business Law. U.S.A.: South-Western Publishing Company. Saturday Punch (16-5-2009). Punch (Nig.) Limited, Olu Aboderin Street, Onipetesi, Ikeja, Lagos.

\section{Copyrights}

Copyright for this article is retained by the author(s), with first publication rights granted to the journal.

This is an open-access article distributed under the terms and conditions of the Creative Commons Attribution license (http://creativecommons.org/licenses/by/4.0/). 